\section{The impact of immigration on tuberculosis and HIV burden between Colombia and Venezuela and across frontier regions}

\author{
El impacto de la inmigración en la tuberculosis y \\ la carga del VIH entre Colombia y Venezuela \\ a través de las regiones fronterizas
}

\section{O impacto da imigração sobre a tuberculose e a carga de HIV entre Colômbia e Venezuela e nas regiões de fronteira}

Nelson Enrique Arenas-Suarez 1,2

Laura I. Cuervo 1

Edier F. Avila 2

Alejandro Duitama-Leal 3

Andrea Clemencia Pineda-Peña 4,5 doi: 10.1590/0102-311X00078820

\author{
Correspondence \\ N. E. Arenas-Suarez \\ Faculdad de Ciencias, Universidad Antonio Nariño. \\ Cra. 1 \# 47a-15, Bogotá/Cundinamarca - 110231, Colombia. \\ narenas69@uan.edu.co \\ 1 Faculdad de Ciencias, Universidad Antonio Nariño, Bogotá, \\ Colombia. \\ 2 Facultad de Ciencias Agropecuarias, Universidad de \\ Cundinamarca, Fusagasugá, Colombia. \\ 3 Facultad Educación, Universidad de Cundinamarca, \\ Fusagasugá, Colombia. \\ 4 Departamento de Biología Molecular e Inmunología, \\ Fundación Instituto de Inmunología de Colombia, \\ Bogotá, Colombia. \\ 5 Facultad de Ciencias Agropecuarias, Universidad de Ciencias \\ Aplicadas y Ambientales, Bogotá, Colombia.
}

tious diseases by promoting the emergence of temporal outbreaks between populations. We aimed to analyze health indicators, expenditure, and disability caused by tuberculosis (TB) and HIV/AIDS burden under the ColombianVenezuelan migration flow focusing on the Northeastern border. A retrospective study was conducted using TB and HIV/AIDS data since 2009. We consolidated a database using official reports from the Colombian Surveillance System, World Health Organization, Indexmundi, the Global Health Observatory, IHME HIV atlas, and Joint United Nations Programme on HIV/AIDS (UNAIDS). Disability metrics regarding DALYs (disability adjusted life years) and YLDs (years lived with disability), were compared between countries. Mapping was performed on ArcGIS using official migration data of Venezuelan citizens. Our results indicate that TB profiles from Colombia and Venezuela are identical in terms of disease burden, except for an increase in TB incidence in the Colombian-Venezuelan border departments in recent years, concomitantly with the massive Venezuelan immigration since 2005. We identified a four-fold underfunding for the TB program in Venezuela, which might explain the low-testing rates for cases of multidrug-resistant TB (67\%) and HIV/AIDS (60\%), as well as extended hospital stays (150 days). We found a significant increase in DALYs of HIV/AIDS patients in Venezuela, specifically, 362.35 compared to 265.37 observed in Colombia during 2017. This study suggests that the Venezuelan massive migration and program underfunding might exacerbate the dual burden of TB and HIV in Colombia, especially towards the Colombian-Venezuelan border.

Tuberculosis; HIV; Drug Resistance; Human Migration 


\section{Introduction}

The massive migration of Venezuelan citizens to Colombia started in 2005. Thereafter, a second exodus occurred in 2010 with the arrival of middle-class individuals escaping from the expropriation policies and devaluation of the Venezuelan currency. Between 2017 and 2019, more than one million Venezuelans arrived in Colombia and around 5,300 people requested asylum, causing a large-scale migratory crisis (United Nations High Commissioner for Refugees. https://data2.unhcr.org/en/ situations/vensit, accessed on 11/Feb/2020). The Venezuelan socio-political situation has prompted exodus, due to the shortage of medicine, decrease in life expectancy, and the spread of several diseases of public health significance 1,2,3. Altogether, the health concerns of Venezuelan migrants are focused on receiving diagnosis, treatment, and social welfare 4,5. The departments of Norte de Santander, Santander, and La Guajira are located on the Colombian-Venezuelan border (Northeastern Region) and constitute a migratory passage towards other Colombian cities or international destinations. These departments have recorded a rise in cases of many communicable diseases including tuberculosis (TB) and HIV/AIDS, which might be boosted by the massive immigration 6,7 .

Tuberculosis affects populations from low and middle-income countries in diverse geopolitical and socioeconomic settings. In 2017, the World Health Organization (WHO) reported 10 million new cases of TB (range 9.0-11.1 million) worldwide, including 1.3 million deaths among HIV-negative patients (range 1.2-1.4 million) and 300,000 deaths among HIV-positive patients (range 266,000$335,000)$. Therefore, the attributable mortality was equivalent to $16 \%$ of notified patients and composes one of the top ten causes of death worldwide produced by a single pathogen 8 . According to the WHO, TB incidences for Colombia and Venezuela in 2017 were 33 and 42 cases per 100,000 inhabitants, respectively.

The main challenges faced by TB control programs are associated with diagnosis, case reporting, and therapeutic outcomes 9. Although Colombia and Venezuela are classified at medium risk for TB, there is limited access to health services due to geographic barriers. Furthermore, case screening and program funding face several persistent problems. Concomitantly, in some regions, missing data might be associated with disease underestimation and, consequently, low screening efforts for respiratory symptomatic subjects 10 . Therefore, disease progression and the emergence of multidrugresistant strains are affected by failures in TB control 11 .

On the other hand, HIV is the causative agent of the AIDS, a disease of public health significance. The Joint Program of the United Nations (UN) has defined a strategy of UNAIDS (for 2016-2021) seeking to end the epidemic of AIDS by 2030 12,13. The number of new HIV infections declined from 3.4 million in 1996 to 1.8 million in 2017, especially in sub-Saharan Africa, the Caribbean, Asia, and the Pacific. In Latin America, the trend of new HIV infections is stable, displaying a 1\% reduction due to the implementation of antiretroviral therapy (ART) coverage. It is estimated that 1.8 million people are living with HIV in this region; most are concentrated in Brazil and Mexico, followed by Colombia and Venezuela. The HIV/AIDS prevalence in the Venezuelan young adult population was $0.6 \%$ in 2016 but increased to $0.9 \%$ in 2017. Furthermore, in Colombia, the prevalence of this disease remained at $0.5 \%$ (0.4-0.6) in recent years (https://www.indexmundi.com/, accessed on 11/Feb/2020). The main challenges faced by the HIV/AIDS control program are focused on early diagnosis, retention in HIV care, sustainable ART supplies, viral suppression, and social stigmatization of patients (UNAIDS. https://aidsinfo.unaids.org/, accessed on 24/Mar/2019) 14.

The ongoing political and economic crisis in Venezuela has been a driver of the public health system collapse, also, the country has been dealing with declining oil prices, excessive government spending, inflation problems, food insecurity, and barriers in accessing health services and treatments. Altogether, the influence of immigration on the burden of certain communicable diseases might be an underestimated and disregarded issue in the Colombian-Venezuelan border, specifically, in the departments of Norte de Santander, Santander, and La Guajira 6,7. Therefore, our purpose was to analyze health indicators, health expenditure, and disability caused by TB and HIV/AIDS epidemics between Colombia and Venezuela after the Venezuelan migration, focusing on the Northeastern border departments. 


\section{Methods}

\section{Study area}

The departments of Norte de Santander (population 1.367 million inhabitants) and Santander (2.071 million inhabitants) are located in Northeastern Colombia, close to the border with Venezuela. Both departments are situated in the Andean region, which is the most densely populated area (70\% population) of Colombia. The department of La Guajira (985,498 inhabitants) is located in the far Northeast, in the Caribbean region, bordering the Southeast with Venezuela.

\section{Migration data and georeferencing analysis}

We compiled map-based information on the displacement of Venezuelan citizens reported in the official figures of the International Office of Migration (IOM) and the Migration Colombia of the Colombian Ministry of Foreign Affairs. These records were consolidated in a geographic database and analyzed using ArcGIS program v10.4 (http://www.esri.com/software/arcgis/index.html) to standardize, to update, and to generate thematic maps associated with migratory flow.

\section{Data collection}

An observational, descriptive, and retrospective study was conducted based on data deposited in the Colombian Surveillance System (SIVIGILA) collected by the Colombian National Institute of Health (INS), the Venezuelan Health Surveillance (OVS), and global registries in Indexmundi, the WHO, and UNAIDS. The observation period was nine years (2009-2018) for TB and HIV according to official notifications from Venezuela and Colombia, including Norte de Santander, Santander, and La Guajira as border departments.

\section{HIVIAIDS and TB data acquisition}

Data from SIVIGILA were collected and analyzed based on weekly bulletins and final reports of communicable diseases such as TB, multidrug-resistant TB (MDR-TB), and HIV/AIDS (https://www. ins.gov.co/buscador-eventos/Paginas/Info-Evento.aspx, accessed on 11/Feb/2020). We consulted annual reports of TB, drug-resistant TB, and HIV/AIDS, focusing on data for La Guajira, Santander, and Norte de Santander. Furthermore, we included only new disease cases, while extrapulmonary $\mathrm{TB}$, relapses, or previous antituberculous cases were excluded. Country profiles were retrieved from official surveillance data from the WHO for TB and MDR-TB, as well as UNAIDS reports (http:// aidsinfo.unaids.org/) for HIV/AIDS. These reports and databases of epidemiological surveillance are consistent and informative regarding the Millennium Development Goals. We conducted an epidemiological analysis using the interactive tool Indexmundi (https://www.indexmundi.com/). Several health indicators were chronologically compared regarding public health status among countries and regions.

Furthermore, records on health expenditure per country were retrieved from the Global Health Observatory (GHO) database (https://www.who.int/gho/countries/col/country_profiles/en/), the Global Health Expenditure Database (GHED), and the Institute for Health Metrics and Evaluation - IHME HIV Atlas (https://hiv.ihme.services/). HIV/AIDS spending trends included development assistance, out-of-pocket, prepaid private, and government. Health care access and quality were retrieved from the Global Burden of Disease (GBD - https://vizhub.healthdata.org/gbd-compare/) according to country profiles for disability-adjusted life years (DALYs). DALY defines an index based on premature death and health-related suffering to portray the total years of healthy life lost due to all causes. We also analyzed the years lived with disability (YLD) by comparing parameters in the VizHub tool at GBD (https://vizhub.healthdata.org/gbd-compare/) 15. YLDs correspond to years of life lived with any short-term or long-term health loss. 


\section{Statistical analysis}

We consolidated the data in Excel to analyze disease rates per 100,000 inhabitants, year, and place. Disease incidence was estimated by comparing the number of cases with population projections for Colombia in 2017, estimated by the National Administrative Department of Statistics (DANE). Comparisons between DALYs and YLDs were performed using non-parametric statistics with the Kruskal-Wallis, Post-hoc, and Wilcoxon tests in the R program v3.6 (http://www.r-project.org).

\section{Ethical aspects}

This study was performed using publicly accessible data available at the INS-SIVIGILA web portal and following the Declaration of Helsinki from the World Medical Association.

\section{Results}

\section{Analysis of the Venezuelan movement into Colombia and other countries}

Tuberculosis and HIV/AIDS have emerged as public threats considering the current socio-economic crisis in Venezuela. Therefore, we compared the migration records of Colombia and Venezuela. The IOM reported an increase in Venezuelan asylum applications to countries in the Andean region, such as Ecuador, Peru, and Chile. Furthermore, IOM estimated that $4.7 \%$ and $5.4 \%$ of the Venezuelan population emigrated between 2016 and 2017, respectively. We mapped the migration of Venezuelan citizens using geographic information systems and thematic maps. Our estimations indicated that Colombia has been the most frequent destination for Venezuelan citizens or it may represent a transit place to migrate to other countries. Venezuelan citizens living in Colombia have applied for 535,650 asylum applications between 2014 and 2018. The number of Venezuelans residing in Colombia was 1,408,055 in June 2019 according to official records from the Ministry of Foreign Affairs of Colombia. When mapping the main national destinations for Venezuelans in Colombia, we found higher concentration in Bogota with 313,528 immigrants (22.3 \%), Norte de Santander 185,433 (13.2\%), La Guajira 163,966 (11.6\%), Atlantico 125,075 (8.8\%), Antioquia 112,745 (8\%), and Santander 69,159 (4.9\%) (Figure 1).

\section{Comparison of TB profiles between Colombia and Venezuela}

The TB rate in Colombia was 20.3 cases per 100,000 inhabitants on average since 2010; however, this estimate varied across departments. Therefore, we analyzed the situation of TB in the ColombianVenezuelan border based on local reports from Santander, Norte de Santander, and La Guajira. TB notifications showed an annual increase in the number of pulmonary and extrapulmonary cases from 2009 to 2017 in Santander and Norte de Santander. Pulmonary TB raised from 452 to 526 cases between 2014 and 2017, and TB incidence increased from 22 to 25.3 cases per 100,000 population in the same period in Santander. The situation in Norte de Santander also increased from 359 to 401 cases with an incidence between 24.3 and 29.1 per 100,000 inhabitants (Figure 2).

Regarding La Guajira, TB records were similar between 2009 and 2010 (31.7 and 34 cases per 100,000 inhabitants, respectively) and these values were comparable to TB cases reported in 2018. TB rates were below 25 cases per 100,000 inhabitants between 2011 and 2016 (Figure 2). Although TB incidence in La Guajira is higher than the national average, some municipalities, such as Dibulla, Maicao, Riohacha, and Uribia, have reported markedly high rates (e.g., 1,336 TB cases per 100,000 inhabitants in Dibulla).

In order to determine the status of the TB control programs in both countries, we compared the country profiles for disease rates, treatment outcomes, drug resistance, patient care, and deaths based on WHO's official records. In 2017, Colombia and Venezuela showed similar TB indicators for disease rates, mortality in HIV-positive and negative patients, and incidence of MDR-TB/RR (i.e., rifampicin resistance). We found a considerably lower percentage of TB cases with known HIV status 


\section{Figure 1}

Estimated size of the Venezuelan population residing in Colombia in 2019 and estimated number of Venezuelan immigrants in South American countries between 2015 and 2017.

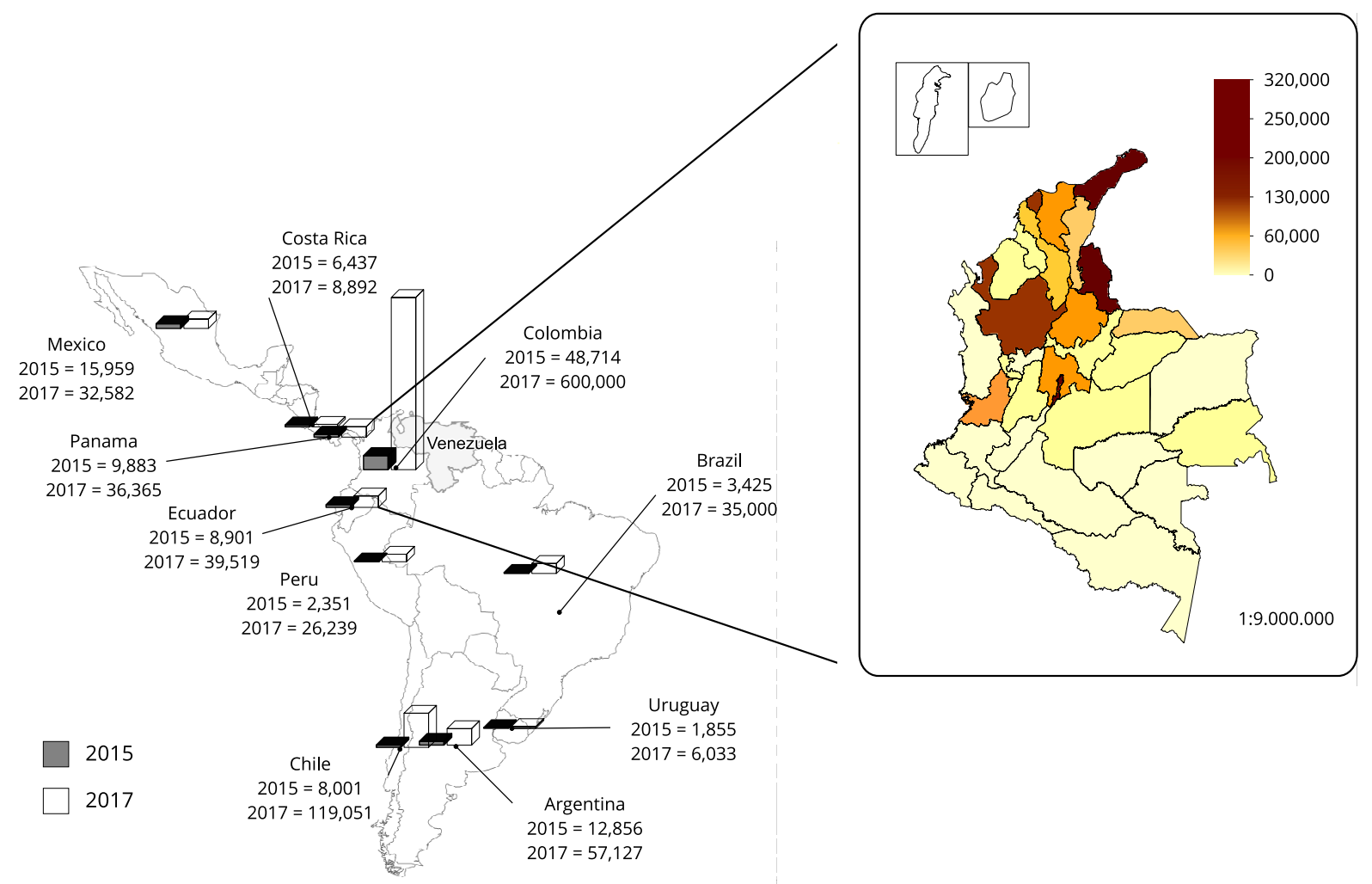

Figure 2

Incidence rate of tuberculosis in the departments of Santander, Norte de Santander, and La Guajira from Colombia between $2009-2018$.

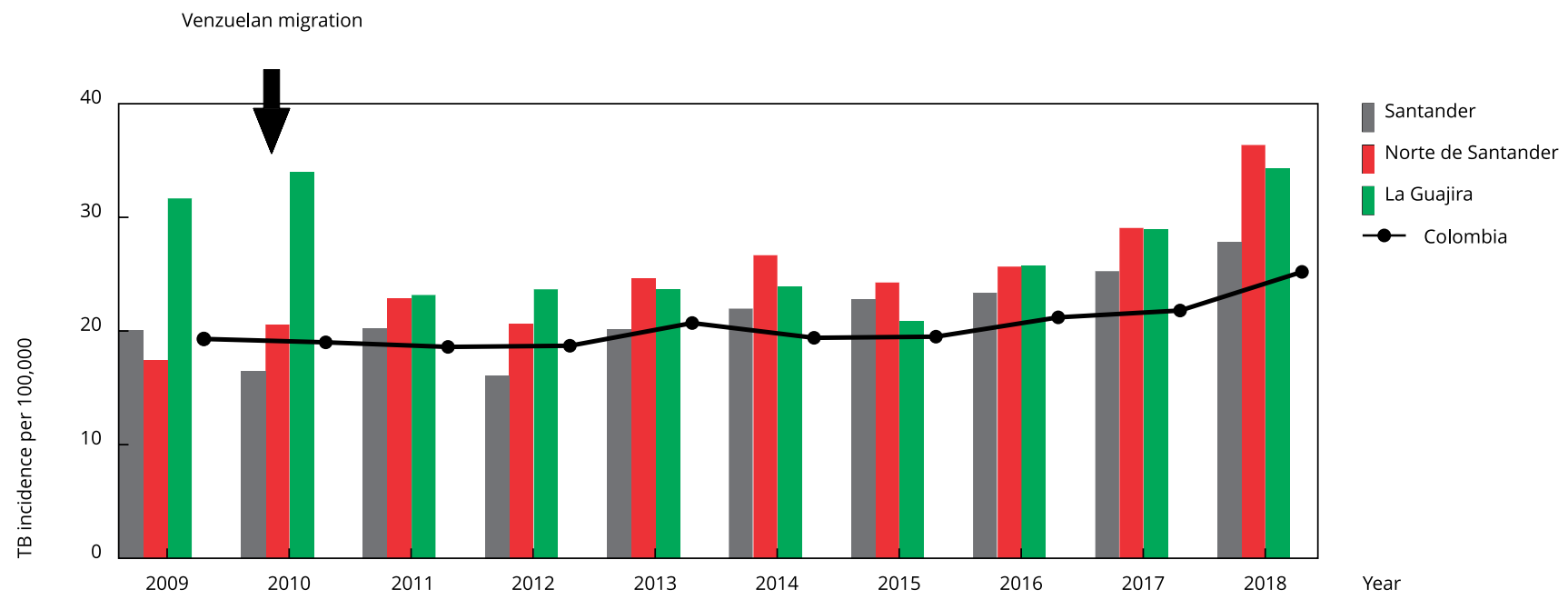

Note: the Venezuelan migration (second exodus) is depicted with black arrows. 
in Venezuela (60\%) compared to Colombia (90\%) (Table 1). Venezuela reported $82 \%$ treatment success rate in new and relapse TB cases and 62\% success in previously treated cases. Moreover, 300 MDR$\mathrm{TB} / \mathrm{RR}$ cases (130-470) were registered, including 5\% new cases, $48 \%$ cases with previous antituberculous treatment, and $22.3 \%$ cases (67) were tested for second-line drug susceptibility in Venezuela. The length of hospital stays in patients diagnosed with MDR-TB increased to 150 days in Venezuela since 2009. On the other hand, for Colombia, 420 MDR-TB/RR cases (310-540) were reported, including $14 \%$ previously treated cases and $22.6 \%$ cases (95) that the individuals received second-line drug susceptibility testing (Table 1). Furthermore, MDR-TB patients did not have prolonged hospital stays. Notification of imported Venezuelan cases increased from three TB cases in 2016 to 29 (63.3\%) cases in 2017 and 220 cases in 2018 (89.8\%).

Regarding TB-related deaths, we observed that Colombia reported a decline from 28.87 deaths (27.24-30.67) per 100,000 inhabitants in 1990 to 17.43 (15.77-19.15) deaths per 100,000 inhabitants in 2017. Similarly, TB mortality in Venezuela decreased from 29.11 deaths (27.6-30.58) in 1990 to 19.38 (17.2-22.02) deaths per 100,000 inhabitants in 2017.

\section{Expenditure in TB and HIV control programs and health actions}

We compared financial health expenditure for both countries since TB indicators can be affected by the lack of health care at the primary level. Our comparative analysis showed that the national budget in 2017 for the TB control program in Venezuela was USD 2.8 million (sources of financing: 14\% domestic, 0\% international, and 86\% non-funded). Furthermore, in Colombia, the budget was UDS 12 million (sources of financing: 31\% domestic, 0\% international, and 69\% non-funded) in the same year. Moreover, the average cost per TB patient has been declining until USD 100 until 2016, and a similar trend was observed regarding expenditures for MDR-TB patients in Venezuela. In Colombia, these values reached USD 200 per patient with susceptible TB and above USD 5,000 per MDR-TB patient. Investment in the HIV/AIDS program in Colombia reached 260 million dollars by 2018 and this funding is expected to increase to more than one billion by 2040 (Figure 3a). Although funding was similar in Venezuela until 2018, these financial resources might have only doubled since then. Consequently, projections for HIV/AIDS incidence in Venezuela show an increase by 2040 (Figure 3b).

Since minimal health care actions can affect the outcomes of many communicable diseases, we determined the current health expenditure (CHE) per capita (USD) for both countries based on reported values in the Global Health Expenditure Database. The CHE per capita in Colombia was consistently $6.0 \%$ and the domestic general government health expenditure (GGHE-D) and health prioritization was $13 \%$ in 2016. On the other hand, CHE per capita in Venezuela was 3.2\% and GGHE-D and health prioritization was $0.8 \%$ in 2016.

\section{Disease effects on TB and HIVIAIDS patients}

Since the decline in health status can promote patient disability, we calculated DALYs for TB and HIV/ AIDS in Colombia and Venezuela. DALYs for TB in Colombia shifted from 194.53 (181.8-207.99) in 1990 to 56.61 (49.03-69.44) in 2017. In Venezuela, DALYs values were 200.68 in 1990 (188.81212.15) and decreased to 79.01 (67.29-95.54) by 2017 (Figure 4a). On the other hand, DALYs for HIV/ AIDS in Colombia were 69 (65.87-72.67) in 1990 and reached 265.37 (251.92-280.43 by 2017. In Venezuela, DALYs were 221.35 (213.73-229.48) in 1990 and increased to 362.35 (342.42-386.11) by 2017 (Figure 4b).

We also compared YLDs from GBD estimates for TB and HIV/AIDS in Colombia and Venezuela, including both genders, all age groups, and units by rate. No major differences in YLDs for TB were observed between both countries. In Venezuela, YLDs were 3.04 (1.95-4.43) in 1990 and decreased to 2.88 (1.89-4.11) in 2017. Similarly, in Colombia, these values were 3.15 (2.03-4.43) in 1990 and declined to 2.76 (1.8-3.79) in 2017. On the other hand, YLDs for HIV/AIDS in Venezuela were 2.35 (1.4-3.78) in 1990 and increased to 31.67 (20.3-49.11) in 2017. For Colombia, YLDs were estimated at 2.7 (1.2-5.34) in 1990 and reached 23.29 (14.54-34.77) in 2017. This index is consistent with the HIV death rates in Venezuela, which were 3.63 per 100,000 inhabitants (3.52-3.75) in 1990 and increased 
Table 1

Comparison between tuberculosis (TB) profiles from Colombia and Venezuela for 2017.

\begin{tabular}{|c|c|c|c|c|}
\hline \multirow[t]{2}{*}{ Estimates of TB burden, 2017 * } & \multicolumn{2}{|c|}{ Colombia } & \multicolumn{2}{|c|}{ Venezuela } \\
\hline & $\begin{array}{l}\text { Number } \\
\text { (thousands) }\end{array}$ & $\begin{array}{l}\text { Rate (per } 100.000 \\
\text { population) }\end{array}$ & $\begin{array}{l}\text { Number } \\
\text { (thousands) }\end{array}$ & $\begin{array}{l}\text { Rate (per } 100.000 \\
\text { population) }\end{array}$ \\
\hline Incidence (includes HIV+TB) & $16(12-21)$ & $33(25-42)$ & $13(10-17)$ & $42(32-53)$ \\
\hline Incidence (HIV+TB only) & $2(1.5-2.5)$ & $4.1(3.1-5.2)$ & $1.2(0.89-1.5)$ & $3.7(2.8-4.8)$ \\
\hline Incidence (MDR/RR-TB) ** & $0.57(0.36-0.84)$ & $1.2(0.73-1.7)$ & $0.42(0.16-0.79)$ & $1.3(0.5-2.5)$ \\
\hline Mortality (excludes HIV+TB) & $1.3(1.1-1.5)$ & $2.6(2.3-3)$ & $0.8(0.75-0.84)$ & $2.5(2.3-2.6)$ \\
\hline Mortality (HIV+TB only) & $0.43(0.32-0.57)$ & $0.88(0.65-1.2)$ & $0.26(0.19-0.35)$ & $0.82(0.59-1.1)$ \\
\hline \multicolumn{5}{|l|}{ TB case notifications } \\
\hline Total cases notified & \multicolumn{2}{|l|}{13,870} & \multicolumn{2}{|l|}{10,952} \\
\hline Total new and relapse & \multicolumn{2}{|l|}{13,007} & \multicolumn{2}{|l|}{10,647} \\
\hline $\begin{array}{l}\text { Percentage tested with rapid diagnostics at time of } \\
\text { diagnosis }\end{array}$ & \multicolumn{2}{|l|}{12} & \multicolumn{2}{|l|}{$\mathrm{nr}$} \\
\hline Percentage with known HIV status & \multicolumn{2}{|l|}{90} & \multicolumn{2}{|l|}{60} \\
\hline Percentage TB pulmonary & \multicolumn{2}{|l|}{83} & \multicolumn{2}{|l|}{89} \\
\hline $\begin{array}{l}\text { Percentage bacteriologically confirmed among } \\
\text { pulmonary }\end{array}$ & \multicolumn{2}{|l|}{80} & \multicolumn{2}{|l|}{76} \\
\hline \multicolumn{5}{|l|}{ Universal health coverage and social protection } \\
\hline $\begin{array}{l}\text { TB treatment coverage (notified/estimated incidence), } \\
2017\end{array}$ & \multicolumn{2}{|c|}{$80 \%(63-100)$} & \multicolumn{2}{|c|}{$80 \%(63-100)$} \\
\hline $\begin{array}{l}\text { TB case fatality ratio (estimated mortality/estimated } \\
\text { incidence), } 2017\end{array}$ & \multicolumn{2}{|c|}{$0.11(0.08-0.14)$} & \multicolumn{2}{|c|}{$0.08(0.06-0.1)$} \\
\hline \multicolumn{5}{|l|}{ TB/HIV care in new and relapse TB patients, 2017} \\
\hline Patients with known HIV-status who are HIV-positive & \multicolumn{2}{|c|}{$1.380(12 \%)$} & \multicolumn{2}{|c|}{$528(8 \%)$} \\
\hline On antiretroviral therapy & \multicolumn{2}{|c|}{$803(58 \%)$} & \multicolumn{2}{|c|}{$300(57 \%)$} \\
\hline Treatment success rate and cohort size & Success & Cohort & Success & Cohort \\
\hline New and relapse cases registered in 2016 & $61 \%$ & 10.021 & $82 \%$ & 8.197 \\
\hline $\begin{array}{l}\text { Previously treated cases, excluding relapse, registered } \\
\text { in } 2016\end{array}$ & $32 \%$ & 893 & $62 \%$ & 345 \\
\hline HIV-positive TB cases registered in 2016 & $38 \%$ & 1.422 & $81 \%$ & 585 \\
\hline $\begin{array}{l}\text { MDR/RR-TB cases started on second-line treatment in } \\
2015\end{array}$ & $40 \%$ & 172 & $71 \%$ & 31 \\
\hline MDR-TB cases started on second-line treatment in 2015 & $0 \%$ & 5 & $100 \%$ & 1 \\
\hline Drug-resistant TB care, 2017 & New cases & $\begin{array}{l}\text { Previously treated } \\
\text { cases }\end{array}$ & New cases & $\begin{array}{l}\text { Previously treated } \\
\text { cases }\end{array}$ \\
\hline Estimated percentage of TB cases with MDR/RR-TB & $2.4(1.5-3.5)$ & $14(11-18)$ & $2.3(0.79-0.45)$ & $13(8.4-18)$ \\
\hline Percentage notified tested for rifampicin resistance & 16 & 22 & 5 & 48 \\
\hline
\end{tabular}

MDR-TB: multidrug resistant TB; nr: no report; RR-TB: resistant to rifampicin.

Note: estimates of the burdens of TB and MDR-TB were estimated based on reports from the TB data collection system of the WHO.

* Rates were estimated based on populations of 49 million inhabitants for Colombia and 32 million for Venezuela. The ranges represent uncertainty ranges;

** MDR/RR-TB: resistant to rifampicin and isoniazid. 
Figure 3

Comparison between HIV incidence rate per 100,000 inhabitants (green line) and total health expenditure on HIV (orange line) in Colombia and Venezuela between 2000-2040.

3a) Colombia
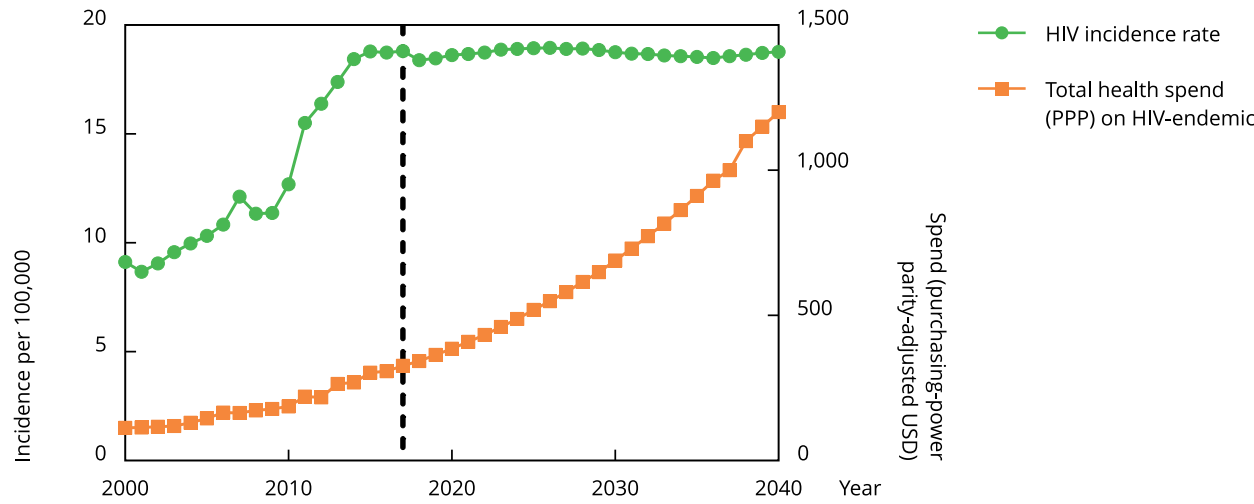

3b) Venezuela
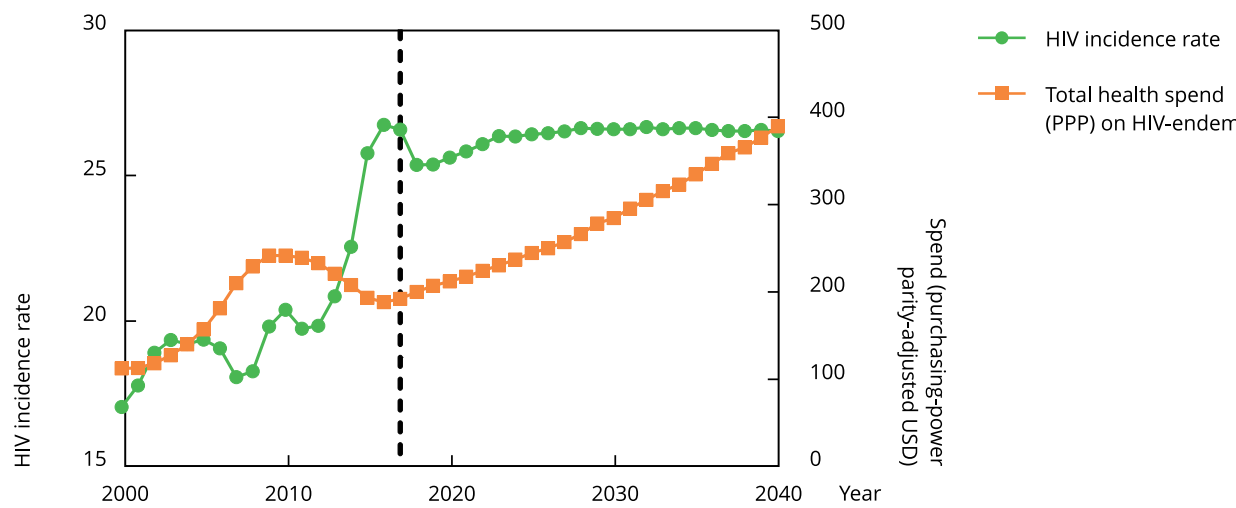

(PPP) on HIV-endemic

Source: Institute for Health Metrics and Evaluation HIV Atlas (https://hiv.ihme.services/).

to 6.9 (6.59-7.23) by 2017. Furthermore, for Colombia, the HIV mortality was 1.32 per 100,000 inhabitants (1.27-1.37) in 1990 and raised to 5.21 (5-5.41) by 2017.

We found a statistical difference in DALYs for HIV/AIDS ( $\mathrm{p}$-value $=0.0006$ ) between Colombia and Venezuela, while no difference was observed in YLDs (p-value $=0.02584$ ) (Supplementary Material - Figure S1. http://cadernos.ensp.fiocruz.br/static//arquivo/suppl-csp-0788-20_1385.pdf). On the other hand, no statistical differences in DALYs ( $\mathrm{p}$-value $=0.3419$ ) and YLDs (p-value $=0.3016)$ for TB were found between countries.

\section{Number of HIV cases in the Colombian-Venezuelan border departments}

HIV control programs in Colombia showed reduced prevalence rates from $0.7 \%$ in 2003 to 0.4 in 2016. Similarly, Venezuela reported reduced HIV/AIDS prevalence among adults, specifically, $0.7 \%$ in 2001 to $0.55 \%$ in 2015 . However, in 2016 , there was a slight increase to $0.6 \%$, indicating an oppo- 


\section{Figure 4}

Disability-adjusted life years (DALYs) trends between Colombia and Venezuela for TB and HIV/AIDS between $1990-2017$.

4a) Tuberculosis

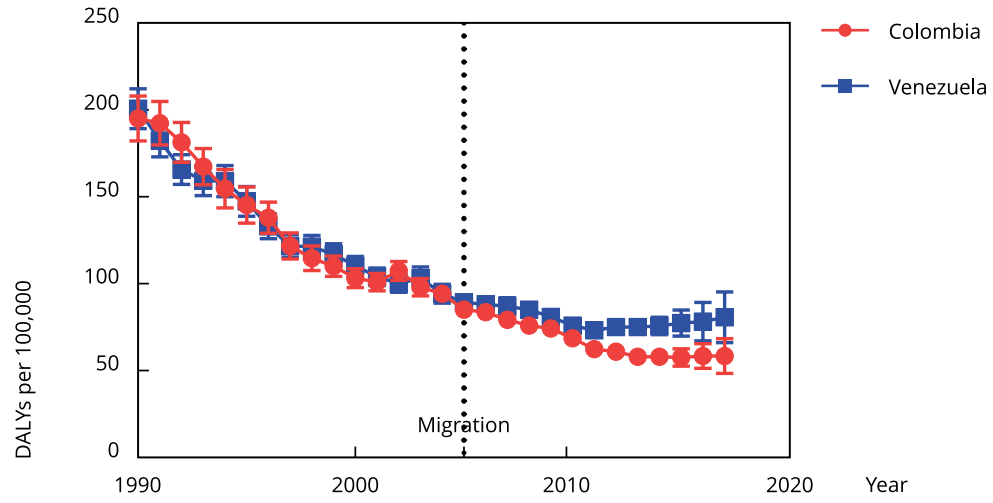

4b) HIV/AIDS

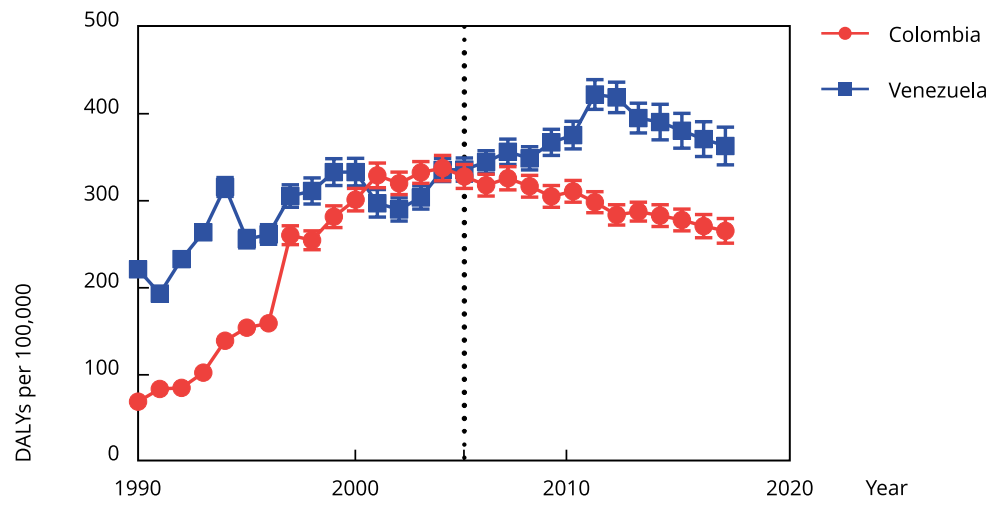

Note: the beginning of massive migration of Venezuelan citizens started in 2005.

site trend for HIV/AIDS prevalence in Venezuela. Consistently, we found an increase in HIV cases in Norte de Santander between 2010 (121 cases) to 2016 (461 cases). This epidemiological situation was similar in Santander, with 372 cases in 2010 to 506 cases in 2017, and La Guajira, with 108 to 176 cases in the same period.

Comparative analyses showed that, in Colombia, 108 HIV cases of foreign origin were reported in 2017, including 90 cases (83\%) from Venezuela, mainly in Norte de Santander and Bogota (25 and 30 cases, respectively). In 2018, official records confirmed 410 cases of foreign origin, including 383 (93.4\%) from Venezuela. Most cases were centered in Bogota (102 cases), followed by Norte de Santander (70 cases), Antioquia (35 cases), Santander (16 cases), and La Guajira (17 cases). Finally, our results indicated that TB is the third most prevalent opportunistic coinfection in people living with HIV in Colombia, accounting for 343 cases and 296 cases in 2017 and 2018, respectively. 


\section{Discussion}

In South America, the highest migrations have occurred from Colombia, Venezuela, Chile, and Brazil and they are driven by low socio-economic conditions, violence, and lack of social welfare 16. The Venezuelan migration crisis has reached an alarming situation, leading to the displacement of nearly 1.6 million people and an increase of asylum applications to Colombia in the last years (United Nations High Commissioner for Refugees. https://data2.unhcr.org/en/situations/vensit, accessed on $11 / \mathrm{Feb} / 2020$ ). The unknown number of Venezuelans that reside illegally in Colombia might be the most vulnerable population to cases of labor exploitation, extortion, violence, illegal trafficking, sexual abuse, forced recruitment, discrimination, and xenophobia 17,18. Assuring health services, education, and other basic services to the migrant population is likely a cumbersome issue in the border departments (i.e., Santander, Norte de Santander, and La Guajira) that requires extra resources, strategies, or immigration policies 19,20 .

The political and socioeconomic situation in Venezuela has exacerbated a crisis in the health system considering the emergence of different infectious diseases that may become the major epidemic focus in the Americas 16,21. In the globalized era, these diseases are preventable, yet they are emerging at an unprecedented speed depending on different environmental and demographic factors, such as human susceptibility to infections, availability of health services, food production, human behavior (e.g., trade and travel), environmental and ecological changes, economic development, war, food depletion, availability of public health infrastructure, and pathogen evolution $4,5,22$. The situation of TB in Venezuela cannot improve without changing the political situation of the country and it is directly affected by the shortage of food, medicine, and vaccines and the impoverishment of medical infrastructure in the concomitant economic crisis 21,23. In addition, precarious access to adequate food, extreme poverty, and scarce health insurance coverage in Venezuela could promote favorable conditions for active TB transmission 24 . The high rate of immigrants and native populations, overcrowding, and poverty can increase the probability of TB spread 25,26 . Thus, areas of low incidence in the Colombian-Venezuelan border can become new foci of active transmission of TB 27.

Another issue arises due to the spread of MDR-TB, which might become a major problem since migration is a current driver of disease transmission 28 . This study describes a severe underfunding of the TB program, which might be associated with possible drug shortage and a considerable number of patients who have abandoned TB treatment in Venezuela, and this issue likely contributes to the rise in MDR-TB cases 16,29. Drug susceptibility testing should be an essential tool for diagnosis, especially in patients who lack adherence to treatment or register failures and possible diseases reactivations. Beyond this situation, possible underestimation of communicable diseases and antitubercular drug shortage can promote unforeseen issues in the national control program 16.

Similar to the scenario of TB, the HIV program in Venezuela reported a 43\% ART shortage and scarcity of 23 drugs, which have affected pregnant women with HIV since 2009 30. Other problems faced by the HIV/AIDS control program arise from late diagnosis, the socio-economic conditions of patients, lack of prevention strategies, and limited testing opportunities 30,31. As a result of migration, disease spread occurs to neighboring countries, such as Colombia, Brazil, Peru, and Aruba, which have already reported alarming rates and difficulties in providing ART treatment 32,33,34. TB remains a frequent opportunistic disease in HIV patients, as suggested in this study; therefore, it is essential to continue with collaborative actions between TB and HIV control programs 35,36,37,38.

The geographic distribution of TB and HIV outbreaks in Colombia and Venezuela shows a progressive displacement of the affected or vulnerable population (e.g. native population). Furthermore, the migrant condition of this population might enhance the spread of these diseases from endemic areas to the Colombian-Venezuelan border departments (e.g., La Guajira, Santander, and Norte de Santander) 39,40,41. The continuous migrations of Venezuelans in precarious conditions are associated with forced displacement, commercial activities, health insurance, and supply of medicines and food $16,21,23$.

According to UNAIDS and the WHO, both countries have made several efforts to scale up national HIV and TB prevention, counseling, testing, and control programs 13 (UNAIDS data. https://aidsinfo. unaids.org/, accessed on 24/Mar/2019). However, progress might be halted due to funding issues that threaten program sustainability and health care, attributed to limited availability of supplies for 
testing, prevention, and immigration 42,43. Thus, changes in patient disability/health loss indicated by DALYs and YLDs, TB and HIV burden might be the consequence of a multifaceted interaction between low funding, poor governance, and enhanced migration flow. Our results regarding high TB and HIV/AIDS burden in Colombian-Venezuelan border departments are also consistent with low human development index, lack of health insurance, high cost of drugs, and malnutrition risk factors 7,44,45,46. Here, we report a shift in DALYs for HIV/AIDS in Venezuela during a 20-year time-frame, which might have been exacerbated by HIV epidemics along with underfunding of the HIV control program. We demonstrate that DALY trends suggest a detriment in healthy life years of the Venezuelan population; therefore, the UNAIDS strategy must be urgently reinforced to avoid a major public health crisis 47,48,49. A related effort from the Colombian government was to issue an urgent and desperate policy in 2018 (CONPES 3950) to define the health care strategy for Venezuelan immigrants 50.

This study limitations are related to possible bias for some TB and HIV/AIDS data from different sources and missing epidemiological data for Venezuela, such as indexes at different scales. However, those differences did not compromise the results and the analysis of this study.

\section{Conclusions}

Venezuela displays more TB patients with unknown HIV-status, prolonged hospital stays, lower susceptibility testing to second-line drugs, lower MDR-TB patients with previous antituberculous treatment, higher HIV/AIDS lethality, increased disability (i.e., DALYs and YLDs), and greater budget deficit compared with Colombia.

Venezuelan immigration could imply a shift in the epidemiological trends of TB, MDR-TB, and HIV rates in Colombia, especially in departments of the Colombian-Venezuelan border.

This study suggests that human migration, underfunding, and poor governance might delay the progress towards the WHO goal to end/reduce the TB and HIV/AIDS epidemics by 2030. 


\section{Contributors}

N. E. Arenas-Suarez conceived the study and collected and analyzed data. L. I. Cuervo interpreted epidemiological data. E. F. Avila interpreted the immigration data. A. Duitama-Leal performed statistical analysis. A. C. Pineda-Peña conceived the study, collected and analyzed the HIV/AIDS data. All authors wrote the manuscript, reviewed and approved the final version of the manuscript.

\section{Additional informations}

ORCID: Nelson Enrique Arenas-Suarez (00000002-7665-8955); Laura I. Cuervo (0000-00016183-7670); Edier F. Avila (0000-0002-8997-9125); Alejandro Duitama-Leal (0000-0002-5477-2191); Andrea Clemencia Pineda-Peña (0000-0003-19370506).

\section{Acknowledgments}

All authors wish to acknowledge the data availability provided by the Colombian Surveillance System - SIVIGILA (INS). The authors also gratefully acknowledge Professor Edwin Correa for his help in the statistical analyses. We thank Oscar Alberto Arenas Suarez for his advice with figures.

\section{References}

1. Paniz-Mondolfi AE, Tami A, Grillet ME, Márquez M, Hernández-Villena J, EscalonaRodríguez MA, et al. Resurgence of vaccinepreventable diseases in Venezuela as a regional public health threat in the Americas. Emerg Infect Dis 2019; 25:625-32.

2. Grillet ME, Hernández-Villena JV, Llewellyn MS, Paniz-Mondolfi AE, Tami A, VincentiGonzalez MF, et al. Venezuela's humanitarian crisis, resurgence of vector-borne diseases, and implications for spillover in the region. Lancet Infect Dis 2019; 19:e149-61.

3. Rodríguez-Morales AJ, Suárez JA, Risquez A, Delgado-Noguera L, Paniz-Mondolfi A. The current syndemic in Venezuela: measles, malaria and more co-infections coupled with a breakdown of social and healthcare infrastructure. Quo vadis? Travel Med Infect Dis 2019; 27:5-8.

4. Greenaway C, Castelli F. Infectious diseases at different stages of migration: an expert review. J Travel Med 2019; 26:taz007.

5. Aagaard-Hansen J, Nombela N, Alvar J. Population movement: a key factor in the epidemiology of neglected tropical diseases. Trop Med Int Health 2010; 15:1281-8.

6. Tuite AR, Thomas-Bachli A, Acosta H, Bhatia D, Huber C, Petrasek K, et al. Infectious disease implications of large-scale migration of Venezuelan nationals. J Travel Med 2018; 25:tay077.

7. Doocy S, Page KR, de la Hoz F, Spiegel P, Beyrer $\mathrm{C}$. Venezuelan migration and the border health crisis in Colombia and Brazil. J Migr Hum Secur 2019; 7:79-91.

8. World Health Organization. Global tuberculosis report, 2018. https://www.who.int/tb/ publications/global_report/en/ (accessed on 30/Nov/2019).

9. Lönnroth K, Castro KG, Chakaya JM, Chauhan LS, Floyd K, Glaziou P, et al. Tuberculosis control and elimination 2010-50: cure, care, and social development. Lancet 2010; 375:1814-29.

10. Arenas NE, Ramírez N, González G, Rubertone S, García AM, Gómez-Marín JE, et al. Estado de la coinfección tuberculosis/virus de la inmunodeficiencia humana en el municipio de Armenia (Colombia): experiencia de 10 años. Infectio 2012; 16:140-7.

11. Khan PY, Yates TA, Osman M, Warren RM, van der Heijden Y, Padayatchi N, et al. Transmission of drug-resistant tuberculosis in HIV-endemic settings. Lancet Infect Dis 2019; 19:e77-e88.

12. Tulloch O, Machingura F, Melamed C. Health, migration and the 2030 Agenda for Sustainable Development. Bern: Swiss Agency for Development and Cooperation; 2016.

13. Programa Conjunto de las Naciones Unidas sobre el VIH/SIDA. Estrategia ONUSIDA 2016-2021. Acción acelerada para acabar con el SIDA. Geneva: Programa Conjunto de las Naciones Unidas sobre el VIH/SIDA; 2018. 
14. Piñeirúa A, Sierra-Madero J, Cahn P, Palmero RNG, Buitrago EM, Young B, et al. The HIV care continuum in Latin America: challenges and opportunities. Lancet Infect Dis 2015; 15:833-9.

15. Reidpath DD, Allotey P. Measuring global health inequity. Int J Equity Health 2007; 6:16.

16. Roa AC. Sistema de salud en Venezuela: ¿un paciente sin remedio? Cad Saúde Pública 2018; 34:e00058517.

17. Muci-Mendoza R. Venezuela: violence, human rights, and health-care realities. Lancet 2014; 383:1967-8.

18. Schwartz SJ, Salas-Wright CP, Pérez-Gómez A, Mejía-Trujillo J, Brown EC, Montero-Zamora $\mathrm{P}$, et al. Cultural stress and psychological symptoms in recent Venezuelan immigrants to the United States and Colombia. Int J Intercult Relat 2018; 67:25-34.

19. Pescarini JM, Rodrigues LC, Gomes MGM, Waldman EA. Migration to middle-income countries and tuberculosis - global policies for global economies. Global Health 2017; 13:15.

20. Cabieses B, Gálvez P, Ajraz N. Migración internacional y salud: el aporte de las teorías sociales migratorias a las decisiones en salud pública. Rev Peru Med Exp Salud Pública 2018; 35:285-91.

21. Jaffe K. Venezuela: violence, human rights, and health-care realities. Lancet 2014; 383:1970.

22. Mackey TK, Liang BA, Cuomo R, Hafen R, Brouwer KC, Lee DE. Emerging and reemerging neglected tropical diseases: a review of key characteristics, risk factors, and the policy and innovation environment. Clin Microbiol Rev 2014; 27:949-79.

23. Robertson E. Venezuelan unrest increases pressure on health services. Lancet 2014; 383:942.

24. Aristimuño L, Armengol R, Cebollada A, España M, Guilarte A, Lafoz C, et al. Molecular characterisation of Mycobacterium tuberculosis isolates in the First National Survey of Anti-tuberculosis Drug Resistance from Venezuela. BMC Microbiol 2006; 6:90.

25. Mokrousov I, Vyazovaya A, Iwamoto T, Skiba Y, Pole I, Zhdanova S, et al. Latin-AmericanMediterranean lineage of Mycobacterium tuberculosis: human traces across pathogen's phylogeography. Mol Phylogenet Evol 2016; 99:133-43.

26. Lönnroth K, Jaramillo E, Williams BG, Dye C, Raviglione M. Drivers of tuberculosis epidemics: the role of risk factors and social determinants. Soc Sci Med 2009; 68:2240-6.

27. Abadía E, Sequera M, Ortega D, Méndez MV, Escalona A, Da Mata O, et al. Mycobacterium tuberculosis ecology in Venezuela: epidemiologic correlates of common spoligotypes and a large clonal cluster defined by MIRU-VNTR-24. BMC Infect Dis 2009; 9:122.

28. Ritacco V, Iglesias M-J, Ferrazoli L, Monteserin J, Dalla Costa ER, Cebollada A, et al. Conspicuous multidrug-resistant Mycobacterium tuberculosis cluster strains do not trespass country borders in Latin America and Spain. Infect Genet Evol 2012; 12:711-7.
29. Burki TK. Ongoing drugs shortage in Venezuela and effects on cancer care. Lancet Oncol 2017; 18:578.

30. Daniels JP. Venezuela's economic crisis hampers HIV/AIDS treatment. Lancet 2017; 10074:1088-9.

31. Bonjour MA, Montagne M, Zambrano M, Molina G, Lippuner C, Wadskier FG, et al. Determinants of late disease-stage presentation at diagnosis of HIV infection in Venezuela: a case-case comparison. AIDS Res Ther 2008; 5:6.

32. Hofstra LM, Sánchez Rivas E, Nijhuis M, Bank LE, Wilkinson E, Kelly K, et al. High rates of transmission of drug-resistant HIV in Aruba resulting in reduced susceptibility to the WHO recommended first-line regimen in nearly half of newly diagnosed HIV-infected patients. Clin Infect Dis 2017; 64:1092-7.

33. Corado AdLG, Bello G, Leão RAC, Granja F, Naveca FG. HIV-1 genetic diversity and antiretroviral drug resistance among individuals from Roraima state, northern Brazil. PLoS One 2017; 12:e0173894.

34. Gómez SA. Increasing cases of HIV/AIDS in the northern region of the Colombia-Venezuela border: the impact of high scale migration in recent years. Travel Med Infect Dis 2018; 25:16-7.

35. Nunn P, Williams B, Floyd K, Dye C, Elzinga $\mathrm{G}$, Raviglione M. Tuberculosis control in the era of HIV. Nat Rev Immunol 2005; 5:819-26.

36. Harries AD, Lin Y, Kumar AM, Satyanarayana S, Takarinda KC, Dlodlo RA, et al. What can National TB Control Programmes in low-and middle-income countries do to end tuberculosis by 2030? F1000Res 2018; 7:F1000.

37. Rebolledo-Ponietsky K, Munayco C, Mezones-Holguin E. Migration crisis in Venezuela: impact on HIV in Peru. J Travel Med 2019; 26:tay 155

38. Carter DJ, Glaziou P, Lönnroth K, Siroka A, Floyd K, Weil D, et al. The impact of social protection and poverty elimination on global tuberculosis incidence: a statistical modelling analysis of Sustainable Development Goal 1. Lancet Glob Health 2018; 6:e514-e22.

39. Buttorff C, Trujillo AJ, Ruiz F, Amaya JL. Low rural health insurance take-up in a universal coverage system: perceptions of health insurance among the uninsured in La Guajira, Colombia. Int J Health Plann Manage 2015; 30:98-110.

40. Villalba JA, Bello G, Maes M, Sulbaran YF, Garzaro D, Loureiro CL, et al. HIV-1 epidemic in Warao Amerindians from Venezuela: spatial phylodynamics and epidemiological patterns. AIDS 2013; 27:1783-91.

41. Belo EN, Orellana JDY, Levino A, Basta PC. Tuberculose nos municípios amazonenses da fronteira Brasil-Colômbia-Peru-Venezuela: situação epidemiológica e fatores associados ao abandono. Rev Panam Salud Publica 2013; 34:321-9. 
42. Dieleman JL, Haakenstad A, Micah A, Moses M, Abbafati C, Acharya P, et al. Spending on health and HIV/AIDS: domestic health spending and development assistance in 188 countries, 1995-2015. Lancet 2018; 391:1799-829.

43. Haakenstad A, Moses MW, Tao T, Tsakalos G, Zlavog B, Kates J, et al. Potential for additional government spending on HIV/AIDS in 137 low-income and middle-income countries: an economic modelling study. Lancet HIV 2019; 6:e382-95.

44. Hernández-Vásquez A, Vargas-Fernández R, Rojas-Roque C, Bendezu-Quispe G. Factores asociados a la no utilización de servicios de salud en inmigrantes venezolanos en Perú. Rev Peru Med Exp Salud Pública 2020; 36:583-91.

45. Higuita-Gutiérrez LF, Figueroa-Huertas ÁA, Cardona-Arias JA. Incidencia de tuberculosis, VIH e Índice de Desarrollo Humano en Colombia: un análisis por departamentos 20052014. Infectio 2019; 23:215-21.

46. Gil-González D, Carrasco-Portiño M, VivesCases C, Agudelo-Suárez AA, Bolea RC, Ronda-Pérez E. Is health a right for all? An umbrella review of the barriers to health care access faced by migrants. Ethn Health 2015; 20:52341.
47. Gold MR, Stevenson D, Fryback DG. HALYS and QALYS and DALYS, Oh My: similarities and differences in summary measures of population Health. Annu Rev Public Health 2002; 23:115-34.

48. Murray CJ. Quantifying the burden of disease: the technical basis for disability-adjusted life years. Bull World Health Organ 1994; 72:42945.

49. Thacker SB, Stroup DF, Carande-Kulis V, Marks JS, Roy K, Gerberding JL. Measuring the public's health. Public Health Rep 2006; 121:14-22.

50. Departamento Nacional de Planeación, Consejo Nacional de Política Económica y Social República de Colombia. Documento CONPES 3950. Estrategia para la atención de la migración desde Venezuela. https:// colaboracion.dnp.gov.co/CDT/Conpes/ Econ\%C3\%B3micos/3950.pdf (accessed on 25/ $\mathrm{Jul} / 2019)$. 


\section{Resumen}

Históricamente, las migraciones humanas han determinado la expansión de muchas enfermedades infecciosas, promoviendo el surgimiento de brotes temporales en la población. Nuestro objetivo fue analizar indicadores de salud, gastos, así como la discapacidad causada por la tuberculosis (TB) y la carga del VIH/SIDA ante el flujo migratorio entre Colombia-Venezuela, centrándose en los departamentos fronterizos del nordeste. Se realizó un estudio retrospectivo usando datos sobre TB y VIH/ SIDA desde 2009. Consolidamos una base de datos usando informes oficiales del Sistema de Vigilancia Colombiano, Organización Mundial de la Salud, Indexmundi, Observatorio Global de la Salud, IHME HIV atlas, y Programa Conjunto de las Naciones Unidas sobre el VIH/SIDA (ONUSIDA). Se midió la discapacidad en términos del DALYs (incapacidad ajustada por años de vida) y YLDs (años vividos con discapacidad) y se compararon entre ambos países. El mapeo se realizó en ArcGIS, usando datos oficiales de migración de ciudadanos venezolanos. Nuestros resultados indican que los perfiles de TB de Colombia y Venezuela son idénticos, en lo que se refiere a la carga de la enfermedad, excepto por el incremento en la incidencia de TB en los departamentos fronterizos de la frontera entre Colombia y Venezuela en años recientes, concomitantemente con la inmigración masiva venezolana desde 2005. Identificamos una cuadruplicación de la subfinanciación para el programa de TB en Venezuela, que podría explicar las bajas tasas de test para los casos multirresistentes a medicamentos contra la TB (67\%) y VIH/SIDA (60\%), al igual que las estancias prolongadas en el hospital (150 días). Hallamos un incremento significativo en DALYs de pacientes con VIH/SIDA en Venezuela, específicamente, 362,35 comparados con los 265,37 observados en Colombia durante 2017. Este estudio sugiere que la migración venezolana masiva y la subfinanciación del programa podrían haber exacerbado la doble carga de la $T B$ y el VIH en Colombia, especialmente a través de la frontera entre Colombia y Venezuela.

Tuberculosis; VIH; Resistencia a Medicamentos; Migración Humana

\section{Resumo}

Historicamente, as migrações humanas determinaram a propagação de muitas doenças infecciosas ao facilitar surtos temporais entre populações. $O$ estudo buscou analisar os indicadores sanitários $e$ os gastos e taxas de incapacidade relacionados à tuberculose (TB) e à carga de HIV/aids no fluxo migratório entre Colômbia e Venezuela, com destaque para os departamentos (estados) da fronteira nordeste. Foi realizado um estudo retrospectivo de dados sobre TB e HIV/aids desde 2009. Consolidamos uma base de dados a partir de relatórios do Sistema de Vigilância da Colômbia, Organização Mundial da Saúde, Indexmundi, Observatório de Saúde Global, IHME HIV Atlas e Programa Conjunto das Nações Unidas sobre HIV/ AIDS (UNAIDS). As métricas de incapacidade em termos de AVAIs (anos de vida ajustados para incapacidade) e AVIs (anos vividos com incapacidade) foram comparadas entre os dois países. $O$ mapeamento foi realizado no ArcGIS, com dados oficiais sobre migração de cidadãos venezuelanos. Nossos resultados indicam que os perfis de TB da Colômbia e da Venezuela são idênticos em termos de carga de doença, exceto por um aumento da incidência de TB nos departamentos na fronteira entre os dois países em anos recentes, concomitantemente com a imigração venezuelana maciça desde 2005. Identificamos um subfinanciamento (por um fator de quatro) no programa de tuberculose da Venezuela, o que pode explicar as baixas taxas de testagem para casos de TB multirresistente (67\%) $e$ HIV/aids (60\%), além das internações hospitalares prolongadas (150 dias). Encontramos um aumento significativo de AVAIs em pacientes de HIV/aids na Venezuela, especificamente 362,35 comparado com 265,37 na Colômbia em 2017. O estudo sugere que a migração maciça venezuelana e o subfinanciamento podem exacerbar a carga dupla de $T B$ e HIV na Colômbia, principalmente na fronteira com a Venezuela.

Tuberculose; HIV; Resistência a Medicamentos; Migração Humana

Submitted on 16/Apr/2020

Final version resubmitted on 12/Aug/2020

Approved on 17/Aug/2020 